\title{
A STUDY ON BENTHOS ABUNDANCE IN FRESHWATER LABHANSARAD DAM OF WARORA TALUKA, DISTRICT-CHANDRAPUR MAHARASHTRA INDIA.
}

\author{
S. Khiratkar ${ }^{1}$ S. K. Waware ${ }^{2}$ R. R. Kamdi ${ }^{3}$ \\ ${ }^{1}$ Center for Higher Research and Learning, S. P. College, Chandrapur. \\ ${ }^{2}$ Gramgeeta Mahavidyalaya, Chimur. \\ ${ }^{3}$ Anand Niketan College, Warora.
}

\begin{abstract}
:
During this research findings four groups of benthos i.e. Oligochaeta, Chironomidae, Mollusca and Unidentified were distinguished during the study period of one year of session, 2016-2017 respectively. Oligochaeta was dominant among different groups of benthos. The highest total number of benthos abundance was recorded in Site-3 due to its comparatively better water quality. The research findings will be beneficial for the pond owners for the improvement of homestead fish production. However, this findings was conducted to address the actual scenario of Labhansarad dam of Warora Taluka, District.Chandrapur. Maharashtra. India. This research findings of freshwater dam on study of benthos abundance were carried out during the session of year $2016-2017$ respectively. Benthos of various species are play an important role for the identification of suitable water for irrigation as well as drinking purposes. However some interference of human beings activities may consider as a threatening to the benthos as well as other some aquatic living organisms presence in the dam. Hence the occurrence of benthos can be considered as a bio indicators of pollution of water and health of ecosystem of a dam allover. This research findings of the present work would be very useful for the welfare of the management and conservation of benthos from this area of nearby villagers for various purposes to fulfill their requirements.
\end{abstract}

Key words: benthos abundance, health, threatening, aquatic, pollution.

\section{INTRODUCTION:}

The research findings of different species of benthos under different adverse conditions of environments always depends on the naturally occurring optimum water quality. Survival, health and adequate growth of benthos species also depend on the significant role of good water quality. Thus, the knowledge of various benthos species of freshwater along with water quality parameters of the inland freshwater bodies provides an important tool for successful production of aquatic variety of an organisms in aquaculture. The abiotic environment of the water body directly causing the essential influences on the distribution, population density and diversity of the macro benthic community as well as its quality depend on the presence of fishes in the water feeds to various benthos species. In the present study, water temperature was found to a favorable limit for fish culture which is also similar to Kunda et al. (2015), Wahab (2013), Dewan et al. (2017). Occurrence of abundance of variety of benthic organisms in any aquatic inland stagnant water body are play an important role which is rich in amino acids, fatty acids, vitamins and minerals, respectively; can alone provide a complete diet for many bottom feeding fishes in inland water body dams. It not only serves as an important food item for fishes, but also considered as an indicator of productivity of a water body. Similar with the findings of Kohinoor et al. (2012). In scientific culture and management of fisheries resources, there is a great need of understanding regarding benthic fauna as they play a vital role in regulating the aquatic environment living organisms in the dam. It also serves domestic purposes like personal hygiene, washing of clothes, dishes and household materials, bathing of cattle etc. Moreover, these ponds contain heavy silt particles and domestic wastes and decomposed organic toxic plastic materials from the neighboring houses. The present findings are similar to the observation of Uddin (2016). Poor performance of the fish growth and high rate of mortality occurs during 
culture period sometimes. Since benthos is suitable indicator for better water quality as well as increases the survival and growth of aquatic organism thus estimation of benthos abundance along with various water quality parameters of those homestead dams are essential. In Chandrapur District, several researches regarding water quality parameters of dams and benthos abundance have been carried out such as monthly variation of plankton in relation to physico-chemical properties of water, effects of water quality on pond ecology and growth performances of fishes, depth wise abundance of benthic fauna, study of different benthic organisms including its biology, structure and life cycle. Mairs (2011) reported that water bodies having alkalinity $40 \mathrm{mgl}-1$ or more considered more productive. According to Alikhunhi (2016), total alkalinity more than 100 mgl-1 should be present in highly productive water bodies.Most of these researches were performed around greater in Chandrapur district in this Maharashtra State of India. However, this experiment was conducted to address the actual scenario of homestead ponds of Labhansarad Dam of Warora Taluka district of Chandrapur.

\section{Objectives of the study}

The major objectives of the present study were as follows-

1. To monitor the monthly changes of various water quality parameters in different water bodies.

2. To identify and quantify different groups of benthos.

3. To observe the response of fishes to the physico-chemical and biological parameters of water.

\section{MATERIAL AND METHODS:}

\section{Study area and site selection}

The study was conducted in Labhansarad dam for a period of one year from March 2016 to May 2017. The experimental dam were selected from Warora Taluka of Chandrapur District. Maharashtra.India. In order to observe the benthic fauna of the dam, samples were collected at 15 days interval. Dam were selected by size, shape, water color and surrounding conditions. Present study includes three treatment where treatment 1 (T1), treatment 2 (T2) and treatment 3 (T3) respectively and each of them had three replications.

Collection of benthos samples

The benthic macro-invertebrate samples were collected from 3 different locations of each pond by using an Ekman dredge (covering an area of lower mouth $225 \mathrm{~cm}$ ). After collecting, the bottom materials were passed through a $0.2 \mathrm{~mm}$ mesh sieve in order to separate benthic organisms. Collected organisms were washed and preserved in $10 \%$ formalin. Finally, samples were taken to laboratory for further analysis.

Separation, identification and calculation of benthic fauna

Benthic samples were kept in a petri dish and washed with tap water to remove the remaining washable detritus and mud. The samples were then cleared using distilled water. The organisms were separated from each other with the help of sorting needles and fine forceps. Subsequently, the benthic organisms were identified and counted according to different taxonomic groups. The abundance of benthic organism was expressed as density (ind.m-2) by following the formula of Welch (2011).

$$
\mathrm{N}=\frac{\mathrm{O} \times 10000}{\mathrm{~A} \times \mathrm{S}}
$$

Where, $\mathrm{N}=$ Number of macroscopic organisms of pro-fundal bottom (m-2); $\mathrm{O}=$ Number of organisms actually counted; $\mathrm{A}=$ Transverse area of Ekman dredge in $(\mathrm{cm} 2)$ and $S=$ Number Samples taken at one sampling station.

\section{Statistical analysis}

For the statistical analysis, a one-way ANOVA and DMRT (Duncan's Multiple Range Test) was performed by using the SPSS (Statistical Package for Social Science) version-16. Significance of mean values was tested at $0.05 \%$ level. 


\section{RESULT \& DISCUSSION:}

\section{Abundance of benthic fauna}

Benthos population of the study ponds were composed of four major groups: Oligochaeta, Chironomidae, Mollusca and unidentified benthos. Mean abundance of benthos in the experimental dam are shown in Table: 1

Oligochaeta (ind.m-2):-The mean ( $\pm \mathrm{SD}$ ) abundances of Oligochaeta were found $363.79 \pm 61.13,360.49 \pm 46.99$ and $383.54 \pm 35.09$ ind. $\mathrm{m}-2$ respectively in $\mathrm{T} 1, \mathrm{~T} 2$ and $\mathrm{T} 3$ (Table 1).The statistical analysis showed that there was no significant difference $(P>0.05)$ among three treatments.

\section{Chironomidae (ind.m-2)}

The mean $( \pm \mathrm{SD})$ abundances of Chironomidae were found $115.23 \pm 30.34,107.41 \pm 31.03$ and $125.10 \pm 29.73$ ind. $\mathrm{m}-2$ respectively in $\mathrm{T} 1, \mathrm{~T} 2$ and T3 (Table 1).The statistical analysis showed that there was no significant difference $(P>0.05)$ among three treatments.

\section{Mollusca (ind.m-2)}

The mean $( \pm \mathrm{SD})$ abundances of Mollusca were found $16.46 \pm 8.90,11.11 \pm 9.21$ and $16.46 \pm 15.62$ ind.m-2 respectively in T1, T2 and T3 (Table 1).The statistical analysis showed that there was no significant difference $(P>0.05)$ among three treatments.

\section{Unidentified benthos (ind.m-2)}

The mean $( \pm \mathrm{SD})$ abundances of unidentified benthos were found $31.28 \pm 8.90,19.75 \pm 13.15$ and $27.98 \pm 11.58$ ind.m-2 respectively in T1, T2 and T3 (Table 2).The statistical analysis showed that the values were significant different $(P<0.05)$ among three treatments.

\section{Total benthos (ind.m-2)}

The mean $( \pm \mathrm{SD})$ abundances of total benthos were found $526.75 \pm 76.30,498.77 \pm 68.72$ and $553.09 \pm 61.53$ ind. $\mathrm{m}-2$ respectively in $\mathrm{T}, \mathrm{T}$ and $\mathrm{T}$ (Table 2).The statistical analysis showed that there was no significant difference $(P>0.05)$ among three treatments.

In the present study, the dominant groups of benthic organisms were Oligochaeta> Chironomidae $>\quad$ unidentified $>$ Mollusca respectively i.e. Oligochaeta was found the most dominant group throughout the experimental period while Chironomidae was the second dominant group followed by the unidentified and Mollusca. These are similar to the findings of Das and Islam (2013) as they reported that Oligochaeta, Chironomidae and Mollusca were the dominant macro-benthos in tropical freshwater ponds and Oligochaeta was the most dominant group followed by Chironomidae and Mollusca which complies with the observation of Kunda et al. (2015). Similar results were also reported by Mahato et al.(2014), Ignat et al. (2010), Soechting (2012). According to Chowdhury (2016), the comparative abundance of benthos ought to be high in the fertilized pond whereas marginal in the unfertilized ponds. Soechting (2012) concluded that the abundance of species composition of the benthic organisms was distinctly increasing with the application of fertilizers. In this study, the mean abundance of benthos was comparatively low. It might be due to not using fertilizers in the experimental ponds.

\section{CONCLUSION:}

Present investigation therefore, stated that the causes of low fish production and high rate of fish mortality in these experimental ponds might be due to lack of proper management of water quality. Pollutants from different sources such as domestic wastes, surface run-off, washing of clothes, residues from traditional fish farming system etc. are entering into the ponds and creating the environment unsuitable for fish culture. Proper management of water quality parameters by controlling agricultural, urban and storm water run-off, maintaining septic system and applications of fertilizers would have 
probably the most effective measures to improve the fish production in these ponds. From this short-term survey on benthos abundance and physico-chemical parameters, it could be concluded that there is an urgent need for additional research for betterment of water quality and sustainable production of fish in this region.

\section{ACKNOWLEDGEMENT}

The authors are grateful to the Dr. R. P. Ingole, Principal, S. P. College, Chandrapur, Dr.A A.Dhamani, Principal, Gramgeeta Mahavidyalaya, Chimur and Dr.Mrunal Kale, Principal, Anand Niketan College, Warora for their cordial support and authorities of water quality and pond dynamics laboratory; Department of Zoology. Gondwana University, Gadchiroli. Maharashtra. India.

\section{REFRENCES:}

Alikhunhi KH. (2016). Fish culture in India. Farm Bull., Indian Council of Agricultural Research, New Delhi, 144.

Chowdhury MAH. (2016). A comparative study on the abundance of benthos in fertilized and unfertilized pond. MS Thesis, Dept. of Aquaculture, Bangladesh Agricultural University, Mymensingh, Bangladesh.95.

Das M, Islam MA.(2013). A study on the macrobenthos of an artificial pond in Agricultural University campus. Bangladesh Journal of Aquaculture. 2:111.

Dewan S, Wahab MA, Beveridge MCM, Rahman MH,Sarker BK. (2017). Food selection, electivity and dietary overlap among planktivorous Chinese and Indian major carps fry and fingerling grown in extensively managed rain fed ponds in Bangladesh. Aquaculture and Fish manage. 3:277-294.

Ignat GS, Florescu C, Vadineanu A, Nafornita G,Risnoveanu G et al.(2010) Structure and dynamics of benthic fauna From
Danube Delta. Analalastintifice-deInstutui-de-cercelare-si-Proiectare-Delta-

Dunarii-Tulcea (Romania). Statiunea hindrobioligica.3:87-94.

Kohinoor AHM. (2012). Development of culture technology of three small indigenous fish mola (Amblypharyngodonmola), punti (Puntius sophore) and chela (Chela cachius) with notes on some aspects of their biology. PhD Dissertation, Department of Fisheries Management, Bangladesh Agricultural University, Mymensingh, Bangladesh. 363.

Kunda M, Azim ME, Wahab MA, Dewan S, Roos $\mathrm{N}$ et al.(2015). Potential of mixed culture of freshwater prawn, Mascrobrachium rosenbergii and self-recruiting small species mola, Amblypharyngodon mola in rottional ricefish prawn culture systems in Bangladesh. Aquaculture.

2008; 39:506-517.

Mahato B, Kumar M, Sinha MP, Panday PN.(2014). Studies on some aspects of community composition and relative abundance of invertebrate macro benthic fauna of a newly constructed tropical reservoir. Advances inzoolo India.200-208.

Mairs DR. (2011). A total alkalinity atlas for Maine lake waters. Limnology and Oceanography. 11:68-72.

Soechting W. (2012). The influence of lime fertilizations on the benthic macrofauna of oberer Grumbacher Teich near Hahnenklee Brckswiese (Haz Mountains). Braunschw-Naturkd-Schr. 3:499-506.

Uddin MM.(2016). Effects of addition of small fish on pond ecology and production in polyculture, MS thesis, Dept. of Fisheries Management, Bangladesh Agricultural University, Mymensingh, Bangladesh. 99.

Wahab MA. (2013). Studies on Chironomidae of fish ponds at Howietourm, Stirling, Central Scotland. Bangladesh Journal of Fisheries. 11:91-99. 
Table 1: Mean ( \pm SD) values of different groups of benthic fauna (ind.m-2) observed in three different treatments.

\begin{tabular}{|c|c|c|c|c|}
\hline \multirow[t]{2}{*}{ Group } & \multirow{2}{*}{ 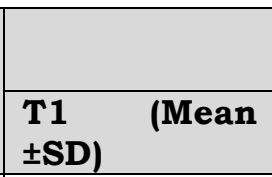 } & \multicolumn{2}{|l|}{ Treatments } & \multirow{2}{*}{\begin{tabular}{|lr} 
Level of \\
Significance
\end{tabular}} \\
\hline & & $\begin{array}{ll}\text { T2 } & \text { (Mean } \\
\pm \text { SD) } & \end{array}$ & $\begin{array}{ll}\text { T3 } & \text { (Mean } \\
\pm \text { SD) } & \end{array}$ & \\
\hline Oligochaeta & $363.79 \pm 61.13$ & $360.49 \pm 46.99$ & $383.54 \pm 35.09$ & NS \\
\hline Chironomidae & $115.23 \pm 30.34$ & $107.41 \pm 31.03$ & $125.10 \pm 29.73$ & NS \\
\hline Mollusca & $16.46 \pm 8.90$ & $11.11 \pm 9.21$ & $16.46 \pm 15.62$ & NS \\
\hline Unidentified & $31.28 \pm 8.90^{\mathrm{b}}$ & $19.75 \pm 13.15 a$ & $27.98 \pm 11.58 \mathrm{ab}$ & $*$ \\
\hline Total Benthos & $526.75 \pm 76.30$ & $498.77 \pm 68.72$ & $553.09 \pm 61.53$ & NS \\
\hline
\end{tabular}

Note: NS $=$ Mean values are not significantly different $(P>0.05) .{ }^{*}$ Mean values with different Superscript letters in the same row indicate significant different at $5 \%$ significance level. 